UDK $577.1: 61$

ISSN 1452-8258

J Med Biochem 37: 307-312, 2018

Original paper

Originalni naučni rad

\title{
IMMUNOGLOBULIN HEAVY CHAIN GENE REARRANGEMENTS IN PATIENTS WITH GAUCHER DISEASE
}

\author{
REARANŽMANI GENA ZA TEŠKI LANAC IMUNOGLOBULINA U BOLESNIKA \\ SA GOŠEOVOM BOLEŠĆU
}

\author{
Predrag Rodić1,2, Milan Lakočević3, Sonja Pavlović ${ }^{4}$,Teodora Karan Đurašević4, Tatjana Kostić4, \\ Nada Suvajdžić Vuković ${ }^{1,5}$, Zorica Šumarac ${ }^{1,6}$, Milan Petakov1,3, Dragana Janić ${ }^{1,2}$ \\ ${ }^{1}$ School of Medicine, University of Belgrade, Serbia \\ ${ }^{2}$ Department of Hematology and Oncology, University Children's Hospital, Belgrade, Serbia \\ ${ }^{3}$ Clinic for Endocrinology, Diabetes and Metabolic Diseases, Clinical Center of Serbia, Belgrade, Serbia \\ ${ }^{4}$ Institute of Molecular Genetics and Genetic Engineering (IMGGE), University of Belgrade, Belgrade, Serbia \\ ${ }^{5}$ Clinic of Hematology, Clinical Center of Serbia, Belgrade, Serbia \\ ${ }^{6}$ Center for Medical Biochemistry, Clinical Center of Serbia, Belgrade, Serbia
}

\section{Summary}

Background: Several studies support the evidence of increased incidence of hematological complications in Gaucher disease including monoclonal and polyclonal gammopathies and blood malignancies, especially multiple myeloma.

Methods: Serum concentrations of immunoglobulins and PCR analysis of the IGH gene rearrangements were performed. The clonal PCR products were directly sequenced and analyzed with the appropriate database and tools. Serum monoclonal proteins were detected and identified by electrophoresis.

Results: Among 27 Gaucher patients, clonal IGH rearrangement was discovered in eight, with $5 / 8$ having also serum monoclonal protein. Elevated immunoglobulins were detected in 9/27 patients. Follow-up data for 17 patients showed that the clonal rearrangement remained the same in four of them, however, in one patient it disappeared after the follow-up period. The remaining 12/17 patients were without previous IGH clonal rearrangement and remained so after the follow-up.

Conclusions: Although clonal expansion may occur relatively early in the disease course, at least judging by the IGH gene rearrangements in Gaucher patients, the detected

\section{Kratak sadržaj}

Uvod: Nekoliko studija u literaturi navode dokaze o povećanoj incidenci hematoloških komplikacija u bolesnika sa Gošeovom bolešću, uključujući monoklonsku i poliklonsku gamapatiju i hematološke malignitete, a posebno multipli mijelom.

Metode: Određivana je serumska koncentracija imunoglobulina kao i rearanžman gena za teški lanac imunoglobulina - IGH, PCR analizom. Klonalni PCR produkti su direktno sekvencirani i analizirani koristeći adekvatne alate i baze podataka. Monoklonski proteini seruma su detektovani i identifikovani metodom elektroforeze.

Rezultati: Među 27 bolesnika, klonalni IGH rearanžman je otkriven kod osmoro, od kojih je petoro imalo i monoklonski protein u serumu. Hipergamaglobulinemija je otkrivena u 9/27 bolesnika. Podaci o praćenju za 17 bolesnika su pokazali da je klonalni rearanžman ostao isti u četiri bolesnika, dok je u jednog bolesnika iščezao tokom perioda praćenja. Preostalih 12/17 bolesnika nisu imali klonalni IGH rearanžman niti su ga stekli nakon perioda praćenja.

Zaključak: lako klonska ekspanzija može da nastane relativno rano u toku Gošeove bolesti, barem sudeći prema rearanžmanu IGH gena, detektovani klonovi mogu biti tranzitorni. Pažljivo kliničko praćenje ovih bolesnika je obavezno, uklju-

$\overline{\text { Address for }}$ correspondence:

Predrag Rodić

Department of Hematology and Oncology, University

Children's Hospital

Tiršova 10, 11000 Belgrade, Serbia

Fax: +381-11-362-14-13

e-mail: predrag.rodic@udk.bg.ac.rs

List of abbreviations: GD = Gaucher disease, MGUS = monoclonal gammopathy of undetermined significance, $M M=$ multiple myeloma, IGH = immunoglobulin heavy chain, $\mathrm{SSI}=$ severity score index, TLR = toll-like receptors. 
clones may be transient. A careful clinical follow-up in these patients is mandatory, including monitoring for lymphoid neoplasms, especially multiple myeloma.

Keywords: Gaucher disease, IGH gene rearrangement, B cell clonality, gammopathy, hypergammaglobulinemia, multiple myeloma

\section{Introduction}

Gaucher disease is a rare lysosomal storage disease caused by a deficiency of glucocerebrosidase. Several studies support the evidence of an increased incidence of hematological complications in GD including gammopathies and blood malignancies. Polyclonal gammopathy is common (1-3) as well as monoclonal gammopathy of unknown significance (MGUS), whose prevalence is ranging from $2.2 \%$ to $25 \%(1,4)$. The increased incidence of multiple myeloma $(M M)$ is also reported, ranging from 5.9 to 51.1 times in comparison to normal population $(2,5)$.

Immunoglobulin molecules are heterodimers composed of two identical heavy $(\mathrm{H})$ chains and two identical light $(L)$ chains. Juxtaposed variable regions of $\mathrm{H}$ and $\mathrm{L}$ chains form the antigen-binding site. Immunoglobulin variable region is generated by somatic recombinations between $V$ (variable), D (diversity) and $J$ (joining) gene segments during differentiation of $B$ lymphocytes. Following antigen encounter, as a part of the affinity maturation process in germinal centres of lymphoid follicles, rearranged variable region genes accumulate somatic hypermutations.

The configuration of IG expressed on the surface of a B cell clone represents its specific molecular signature. PCR amplification of IGH (immunoglobulin heavy chain) rearrangements is a method in use for identifying clonality in suspected B lymphoproliferative disorders. Furthermore, in some $B$ cell malignancies (chronic lymphocytic leukemia, follicular lymphoma) the gene repertoire of IGHV-IGHD-IGHJ rearrangements, as well as somatic hypermutational status, represent a powerful independent prognostic marker (6-8). Analysis of clonality of immunoglobulin heavy chain (IGH) gene rearrangements has become an essential method of molecular diagnosis and follow-up in B-cell disorders i.e. lymphoproliferative diseases (9) and has already been applied to Gaucher disease patients (10).

\section{Materials and Methods}

The study was approved by the ethical committee of the School of Medicine, University of Belgrade, Serbia. Patients or parents of the patients gave written informed consent prior to any study specific activities.

Serum concentrations of immunoglobulins ( $\mathrm{IgG}$, $\lg M$ and $\lg A$ ) were measured by nephelometry (Orion Diagnostica, Espoo, Finland). Monoclonal proteins in čujući i nadzor nad limfoidnim neoplazmama, posebno multiplim mijelomom

Ključne reči: Gošeova bolest, rearanžman IGH gena, B ćelijska klonalnost, gamapatija, hipergamaglobulinemija, multipli mijelom

serum samples were detected by capillary zone electrophoresis using a Sebia Capillarys system (Sebia, Evry Cedex, France) as previously described (11). The type of monoclonal protein was identified by immunofixation electrophoresis performed on a Sebia Hydrasys system and agarose gels (12).

Analysis of lgH gene rearrangement was carried out by PCR analysis as previously described (13).

Genomic DNA was isolated using a QIAamp DNA Blood Mini Kit, according to the manufacturer's instructions (Qiagen, Germany).

IGHV-IGHD-IGHJ rearrangements were amplified by multiplex PCR using a mixture of IGHV FR1 family-specific primers (6 primers) and IGHJ familyspecific primers (4 primers) (14). The conditions of the PCR reaction were as described in Karan-Djurasevic et al. (15). Both strands of clonal PCR products were directly sequenced with a BigDye Terminator v3.1 Cycle Sequencing Kit (Applied Biosystems) on a 3130 Genetic Analyzer (Applied Biosystems). The obtained sequences were analyzed using the ImMunoGeneTics database and tools (http: //imgt.cines.fr). Sequences with the identity of the identified IGHV gene to its germline counterpart $\geq 98 \%$ were considered unmutated, and those with an identity $<98 \%$ were considered mutated.

Statistical analysis was performed using the software package IBM SPSS 20. Normal distribution of the data was tested using the Kolmogorov-Smirnov method. The obtained non-parametric data were analyzed using Mann-Whitney's test. The significance level was agreed at 0.05 probability.

\section{Results}

Our study encompassed 27 Gaucher type I adult patients, 15 women (55.5\%) and 12 men (44.5\%), aged 19.2-65.8 years (average $=40.9 \pm 14.2$ years). The disease burden at diagnosis scored by Zimran's severity score index (SSI) (16) ranged from 3 to 21 (average $10.8 \pm 4.8$ ). The initial chitotriosidase activity ranged from 1224 to 43428 (average $12457.8 \pm 9501.8) \mathrm{nmol} / \mathrm{mL} / \mathrm{h}$, while the initial ferritin level was 58-2136 (average $562.2 \pm 563.1$ ) $\mathrm{ng} / \mathrm{mL}$. Eight patients were treatment naïve (29.6\%) while the remaining 19/26 patients (70.4\%) were on enzyme replacement treatment or substrate reduction treatment. Eight patients (29.6\%) had their spleen previously removed due to hypersplenism (Table I). 
Table I Characteristics of the patients and examination results.

\begin{tabular}{|c|c|c|c|c|c|c|c|c|c|c|c|}
\hline ID & sex & age, yrs & SSI & $\begin{array}{c}\text { chitotriosidase, } \\
\mathrm{nmol} / \mathrm{ml} / \mathrm{h}\end{array}$ & $\begin{array}{l}\text { ferritin, } \\
\mathrm{ng} / \mathrm{mL}\end{array}$ & Tx & Sx & IGH & MCP & $H G$ & Mutation \\
\hline 1 & $\mathrm{~F}$ & 19.3 & 7 & 3688 & 58 & 36 & 0 & Monoclonal & no & no & N370S/D409H \\
\hline 2 & $\mathrm{~F}$ & 38.3 & 7 & 4648 & 64 & 36 & 0 & Normal & no & no & N370S/D409H \\
\hline 3 & $\mathrm{~F}$ & 54.0 & 9 & 18354 & 544 & 0 & 8 & Normal & no & yes & N370S/D409H \\
\hline 4 & $\mathrm{~F}$ & 40.4 & 8 & 19960 & 296 & 156 & 0 & Normal & no & no & N370S/R47X \\
\hline 5 & $\mathrm{~F}$ & 30.5 & 9 & 9464 & 330 & 48 & 0 & Normal & no & no & N370S/L444P \\
\hline 6 & $M$ & 42.1 & 3 & 3686 & 432 & 0 & 0 & Normal & no & no & unknown \\
\hline 7 & $M$ & 34.0 & 7 & 12118 & 2136 & 6 & 8 & Normal & no & yes & unknown \\
\hline 8 & $\mathrm{~F}$ & 62.0 & 6 & 7003 & 100 & 0 & 0 & Monoclonal & no & yes & unknown \\
\hline 9 & $\mathrm{~F}$ & 65.8 & 7 & 16784 & 165 & 12 & 0 & Normal & no & yes & N370S/? \\
\hline 10 & $M$ & 27.7 & 8 & 2982 & 1160 & 0 & 0 & Monoclonal & yes & yes & N370S/D409H \\
\hline 11 & $\mathrm{~F}$ & 63.6 & 7 & 22364 & 140 & 0 & 0 & Biclonal & yes & no & N370S/N370S \\
\hline 12 & $\mathrm{~F}$ & 21.3 & 9 & 1224 & 330 & 0 & 0 & Monoclonal & no & no & N370S/? \\
\hline 13 & $M$ & 55.8 & 12 & 6208 & 492 & 132 & 0 & Biclonal & yes & no & N370S/RecNci1 \\
\hline 14 & $M$ & 43.0 & 13 & 25000 & 172 & 60 & 0 & Normal & no & no & N370S/R463H \\
\hline 15 & $\mathrm{~F}$ & 57.5 & 14 & 9553 & 2060 & 123 & 0 & Normal & no & yes & N307S/S107L \\
\hline 16 & $M$ & 49.4 & 6 & 43428 & 97 & 36 & 0 & Normal & no & no & N370S/N370S \\
\hline 17 & $M$ & 35.4 & 15 & 6804 & 1500 & 36 & 0 & Negative & no & yes & N370S/R120W \\
\hline 18 & $M$ & 55.5 & 16 & 26280 & 362 & 168 & 0 & Normal & no & no & N370S/RecNci1 \\
\hline 19 & $\mathrm{~F}$ & 25.0 & 19 & 12456 & 573 & 132 & 22 & Normal & no & no & N370S/RecNci1 \\
\hline 20 & $\mathrm{~F}$ & 33.9 & 12 & 6060 & 495 & 132 & 20 & Biclonal & yes & no & N370S/RecNci1 \\
\hline 21 & $\mathrm{~F}$ & 38.0 & 21 & 6589 & 241 & 140 & 14 & Normal & no & no & N370S/? \\
\hline 22 & $\mathrm{~F}$ & 58.2 & 11 & 2604 & 320 & 156 & 22 & Monoclonal & yes & no & N370S/L444P \\
\hline 23 & $M$ & 41.2 & 11 & 13079 & 186 & 160 & 0 & Normal & no & no & N370S/L444P \\
\hline 24 & $M$ & 19.3 & 19 & 18500 & 698 & 144 & 0 & Normal & no & no & N370S/RecNci1 \\
\hline 25 & $M$ & 38.3 & 6 & 6298 & 447 & 12 & 0 & Normal & no & no & N370S/N370S \\
\hline 26 & $F$ & 54.0 & 19 & 12816 & 1078 & 0 & 31 & Normal & no & yes & N370S/RecNcil \\
\hline 27 & $M$ & 40.4 & 12 & 18411 & 703 & 0 & 25 & Normal & no & yes & N370S/1236_1317de \\
\hline
\end{tabular}

Legend: $M=$ male, $\mathrm{F}=$ female, $\mathrm{SSI}=$ severity score index, $\mathrm{Tx}=$ treatment duration in months, Sx = splenectomy history (in years), $\lg \mathrm{H}=$ rearrangement of $\mathrm{IGH}$ gene, $\mathrm{MCP}=$ monoclonal protein, $\mathrm{HG}=$ hypergammaglobulinemia.

Clonal rearrangement of the IGH gene was discovered in $8 / 27$ patients (29.6\%) while 5 out of these 8 patients also had a demonstrable monoclonal protein in their serum. That leaves three patients with IGH rearrangement as the sole marker of clonal lymphocyte proliferation. Lastly, elevated serum immunoglobulins were present in $9 / 27$ patients (33.3\%). Among these nine, two patients also had monoclonal IGH rearrangement, one with detectable serum monoclonal protein and another without (Table I). In $17 / 27$ patients $(63 \%)$ the follow-up data on clonal proliferation were available with an average follow-up time of 5 years. Among them, there were five patients who had previous clonal rearrangement of the IGH gene. The clonal rearrangement remained the same in four of them, however, in one patient it disappeared after the follow-up period. The remaining 12/17 patients were without previous IGH clonal rearrangement and remained so after the follow-up.

Using the statistical analysis on the previously demonstrated data, the appearance of monoclonal gammopathy did not differ significantly with respect to age, sex, scored disease severity, ferritin level, 
splenectomy status as well as treatment duration. However, among patients with MGUS, the chitotriosidase activity seemed to have been lower in comparison to the patients without clonal gammopathy. On the other hand, among patients with polyclonal gammopathy (hypergammaglobulinemia), the initial ferritin level seemed to have been higher than among patients with normal gammaglobulins. Furthermore, the patients with hypergammaglobulinemia had significantly shorter therapy duration in comparison to other subjects. Age, sex, SSI score, chitotriosidase level and splenectomy did not significantly differ among patients with and without elevated immunoglobulin levels.

All patients with IGH clonality detected by the method using a consensus pair of primers were analyzed for IGHV-IGHD-IGHJ rearrangements. Clonality was detected by the analysis for IGHV-IGHD-IGHJ rearrangements in only one patient who constantly presented IGH clonality during the follow-up study, using a consensus pair of primers. This patient presented with an apparent biclonality in the first round of IGHV-IGHD-IGHJ rearrangement analysis. The detected IGHV-IGHD-IGHJ rearrangement was further analyzed by sequencing and it was found that it was unmutated and composed of IGHV1-2*04, IGHD3$3 * 02$ and IGHJ4*02. However, when the analysis of the same sample was repeated, a different rearrangement was detected (IGHV1-69*01, IGHD3-3*01, IGHJ4*02).

\section{Discussion}

Patients with Gaucher disease obviously have an increased overall risk of malignant neoplasms, especially of multiple myeloma and hematological malignancies (17). The relative risk of $M M$ ranges from 25 to 51.1 in one study (2) and 3.5-12.7 in another (18). Increased incidence of multiple myeloma may be due to the high prevalence of MGUS in these patients and MGUS is considered as a precursor lesion of MM in most patients (19). Progression from MGUS to $M M$ is seen in about $1 \%$ in a period of one year in the general population (20), however, this rate is not known among Gaucher patients although the progression has been described and reported. The prevalence of MGUS in Gaucher disease ranges up to $35 \%$ (17). Of course, as in the general population, the risk of the aforementioned malignancies rises with age, maybe even more markedly among Gaucher patients (21).

In a previous study of our group (10), we analyzed 7 pediatric and 20 adult Gaucher patients for the laboratory and clinical signs of clonal B lymphocyte proliferation. In eleven out of 27 patients (around $40 \%$ ) we demonstrated the presence of B cell clonality, especially in patients of higher age groups. Among them, five had the rearrangement of the IGH gene as the sole marker of lymphocyte clonality. This could be explained by the known fact that not all of the rearrangements of $\mathrm{lg} \mathrm{H}$ genes during $\mathrm{B}$ cell development are functional and do not lead to production of immunoglobulin chains. So, we speculated that B cell clonality might potentially be a better marker than monoclonal protein itself for the follow-up of Gaucher patients at risk for developing MM. According to our follow-up data (available in 17/27 patients), four patients retained their clonal rearrangement, while it could not be detected anymore in one patient. On the other hand, we detected in the present study about $33 \%$ patients with elevated immunoglobulin levels which seem to have correlated with higher ferritin levels. Elevated levels of proinflammatory cytokines such as TNF $\alpha$, IL1 $\beta$ and IL6 have been found in the plasma of GD patients (22) with a consequent inflammatory response implicated in the pathogenesis of many of the clinical manifestations of Gaucher disease including gammopathies, bone disease and a bleeding diathesis (23) with consequently increased ferritin levels which drop significantly during and after ERT.

Most cancers require clonal expansion but not all clones are malignant (24). The examples of clonal disorders which are not malignant neoplasms are myelodysplastic syndromes, chronic $\mathrm{T}$ and NK disorders of granular lymphocytes, myelofibrosis, monoclonal gammopathies, monoclonal B-cell lymphocytosis, mastocytosis and paroxysmal nocturnal hemoglobinuria. Some molecular and immune pathogenetic mechanisms of clonal disorders may overlap with those in malignancies, however, it is not clear how and to what degree the clonal disorder progresses to malignant neoplasm, in which case the two processes form a unique disease continuum. It is known that some of these clones are self-limiting and some of them progress to pathological conditions including neoplasms of immune cells. On the other hand, the link between the physiological and nonphysiological non-malignant immune stimulation also exists forming a basis for clonal selection and proliferation e.g. in acquired immunity, after vaccination or even in autoimmune diseases (24). Also, in our previous study we revealed a higher incidence of antinuclear and anticardiolipin antibodies in Gaucher patients, without overt clinical manifestations, illustrating a phenomenon where chronic antigenic stimulation with undegraded substrate leads to non-specific antibody production (10).

Multiple myeloma is characterized by genomic instability, presented with both structural and numerical chromosome aberrations (25). However, there is not a single pathogenic mutation responsible for progression from MGUS to $M M$ which is seen with a rate of $1 \%$ year (26). Analysis of the variable heavy chain $(\mathrm{VH})$ sequence in $\mathrm{MM}$ was consistent with clonal post-germinal center origin without evidence of hypersomatic mutations (27). On the other hand, MGUS cells showed an ongoing somatic hypermuta- 
tion process which seems to be lost during progression to MM. Origin of MGUS in Gaucher disease is probably related to chronic antigenic stimulation caused by prolonged exposure to undegraded glucocerebroside. MM cells express a wide range of toll-like receptors (TLR) assisting $B$ cells in microbial antigen pattern recognition (28). Ligands specific for TLR induce proliferation and survival of MM cells. Likewise, plasma cells of MGUS overexpress the IL-6 receptor alpha-chain (29). Subsequently, dysregulated expression of TLR and/or overexpression of IL-6 receptor on plasma cells may lead to an excessive reaction to infectious antigens providing an IL-6 dependent autocrine trigger for plasma cell proliferation (19). Similar mechanism might be present in Gaucher disease in the setting of chronic antigen stimulation.

Further analysis of clonality in our patients with positive clonal rearrangement showed that the clonality was detected in only one patient who presented with an apparent biclonal rearrangement in the first round of IGHV-IGHD-IGHJ analysis. The detected IGHV-IGHD-IGHJ rearrangement was further analyzed by sequencing and it was found that it was unmutated and composed of IGHV1-2*04, IGHD3$3 * 02$ and IGHJ4*02. However, when the analysis of the same sample was repeated, a different rearrangement was detected (IGHV1-69*01, IGHD3-3*01, IGHJ4*02). It should be noted, though, that the mutation status of the sequenced rearrangement must be taken with caution, since only a part of the rearrangement was amplified due to the use of FR1 primers. Also, our method for IGHV rearrangement can detect clones with B lymphocyte counts more than $5 \times 10^{9} / \mathrm{L}$ which is typical for patients with chronic lymphocytic leukemia at disease presentation

\section{References}

1. Brautbar A, Elstein D, Pines G, Abrahamov A, Zimran A. Effect of enzyme replacement therapy on gammopathies in Gaucher disease. Blood Cells, Molecules \& Diseases 2004; 32(1): 214-7.

2. de Fost M, Vom Dahl S, Weverling GJ, Brill N, Brett S, Haussinger D, et al. Increased incidence of cancer in adult Gaucher disease in Western Europe. Blood Cells, Molecules \& Diseases 2006; 36(1): 53-8.

3. Jurecka A, Gregorek H, Kleinotiene G, Czartoryska B, Tylki-Szymanska A. Gaucher disease and dysgammaglobulinemia: A report of 61 patients, including 18 with GD type III. Blood Cell Mol Dis 2011; 46(1): 85-7.

4. Pratt PW, Kochwa S, Estren S. Immunoglobulin abnormalities in Gaucher's disease. Report of 16 cases. Blood 1968; 31(5): 633-40.

5. Rosenbloom BE, Weinreb NJ, Zimran A, Kacena KA, Charrow J, Ward E. Gaucher disease and cancer incidence: a study from the Gaucher Registry. Blood 2005; 105(12): 4569-72. or even higher in the relapse setting, which yields sufficient cell counts for reliable mutation status analysis. It may be that all our subjects except one had lower clonal cell counts precluding the mutation status analysis although we were using the highly sensitive method of nested PCR. The disappearance of clonal rearrangement in one patient during the follow-up as well as low clonality detection rate may be due to the fact that the clones or subclones in Gaucher patients gain size in the setting of chronic immune stimulation; however, they may also wane during the natural course of the disease or under therapeutic intervention. If these transient clones survive and persist long enough to proliferate, we may follow them up over time because they might represent premalignant clones. However, it must be stressed that none of our patients developed multiple myeloma during the follow-up.

In conclusion, although clonal expansion may occur relatively early in the disease course, at least judging by the IGH gene rearrangements in Gaucher patients, the detected clones may be transient. A careful clinical follow-up in these patients is mandatory including monitoring for lymphoid neoplasms, especially multiple myeloma.

Acknowledgements. This work was supported by the Ministry of Science and Technological Development, grant no. III 41004 and Genzyme Corporation.

\section{Conflict of interest statement}

The authors stated that they have no conflicts of interest regarding the publication of this article.

6. Agathangelidis A, Darzentas N, Hadzidimitriou A, Brochet X, Murray F, Yan XJ, et al. Stereotyped B-cell receptors in one-third of chronic lymphocytic leukemia: a molecular classification with implications for targeted therapies. Blood 2012; 119(19): 4467-75.

7. Damle RN, Wasil T, Fais F, Ghiotto F, Valetto A, Allen SL, et al. Ig $\vee$ gene mutation status and CD38 expression as novel prognostic indicators in chronic lymphocytic leukemia. Blood 1999; 94(6): 1840-7.

8. Hamblin TJ, Davis Z, Gardiner A, Oscier DG, Stevenson FK. Unmutated Ig V-H genes are associated with a more aggressive form of chronic lymphocytic leukemia. Blood 1999; 94(6): 1848-54.

9. García-Castillo H, Barros-Núñez P. Detection of clonal immunoglobulin and T-cell receptor gene recombination in hematological malignancies: monitoring minimal residual disease. Cardiovasc Hematol Disord Drug Targets 2009; 9: 124-35. 
10. Rodic P, Pavlovic S, Kostic T, Suvajdzic Vukovic N, Djordjevic M, Sumarac Z, et al. Gammopathy and B lymphocyte clonality in patients with Gaucher type I disease. Blood Cells, Molecules \& Diseases 2013; 50(3): 222-5.

11. Yang Z, Harrison K, Park YA, Chaffin $\mathrm{CH}$, Thigpen $B$, Easley PL, et al. Performance of the Sebia CAPILLARYS 2 for detection and immunotyping of serum monoclonal paraproteins. Am J Clin Pathol 2007; 128(2): 293-9.

12. Bossuyt X, Bogaerts A, Schiettekatte G, Blanckaert N. Serum protein electrophoresis and immunofixation by a semiautomated electrophoresis system. Clin Chem 1998; 44(5): 944-9.

13. Green E, McConville CM, Powell JE, Mann JR, Darbyshire PJ, Taylor AM, et al. Clonal diversity of $\mathrm{lg}$ and T-cellreceptor gene rearrangements identifies a subset of childhood B-precursor acute lymphoblastic leukemia with increased risk of relapse. Blood 1998; 92(3): 952-8.

14. Hawkins RE, Zhu D, Ovecka M, Winter G, Hamblin TJ, Long $A$, et al. Idiotypic vaccination against human $B$-cell lymphoma. Rescue of variable region gene sequences from biopsy material for assembly as single-chain Fv personal vaccines. Blood 1994; 83(11): 3279-88.

15. Karan-Djurasevic T, Palibrk V, Kostic T, Spasovski V, Nikcevic G, Srzentic S, et al. Mutational Status and Gene Repertoire of IGHV-IGHD-IGHJ Rearrangements in Serbian Patients With Chronic Lymphocytic Leukemia. Cl Lymph Myelom Leuk 2012; 12(4): 252-60.

16. Zimran A, Sorge J, Gross E, Kubitz M, West C, Beutler E. Prediction of severity of Gaucher's disease by identification of mutations at DNA level. Lancet 1989; 2(8659): 349-52.

17. Arends $M$, van Dussen $L$, Biegstraaten $M$, Hollak CEM. Malignancies and monoclonal gammopathy in Gaucher disease; a systematic review of the literature. Brit J Haematol 2013; 161(6): 832-42.

18. Taddei TH, Kacena KA, Yang M, Yang RH, Malhotra A, Boxer $M$, et al. The underrecognized progressive nature of N370S Gaucher disease and assessment of cancer risk in 403 patients. American Journal of Hematology 2009; 84(4): 208-14.

19. Rajkumar SV. Multiple myeloma. Curr Probl Cancer 2009; 33(1): 7-64.
20. Kyle RA, Rajkumar SV. Monoclonal gammopathy of undetermined significance. Br J Haematol 2006; 134(6): 573-89.

21. Zimran A, Liphshitz I, Barchana M, Abrahamov A, Elstein D. Incidence of malignancies among patients with type I Gaucher disease from a single referral clinic. Blood cells, Molecules \& Diseases 2005; 34(3): 197-200.

22. Barak V, Acker M, Nisman B, Kalickman I, Abrahamov A, Zimran A, et al. Cytokines in Gaucher's disease. Eur Cytokine Netw 1999; 10(2): 205-10.

23. Duman E, Kulaksızoglu S, Çifçi E, Ozulku M. Is there a real correlation between red cell distribution width and peripheral arterial disease? J Med Biochem 2017; 36: 309-13.

24. Risitano AM, Selleri C. Clonal non-malignant hematological disorders: unraveling molecular pathogenic mechanisms to develop novel targeted therapeutics. Transl Med UniSa 2014; 8: 1-3.

25. Neri P, Bahlis NJ. Genomic instability in multiple myeloma: mechanisms and therapeutic implications. Expert Opin Biol Th 2013; 13: S69-S82.

26. Landgren O, Gridley G, Turesson I, Caporaso NE, Goldin $L R$, Baris $D$, et al. Risk of monoclonal gammopathy of undetermined significance (MGUS) and subsequent multiple myeloma among African American and white veterans in the United States. Blood 2006; 107(3): 904-6.

27. Sahota SS, Leo R, Hamblin TJ, Stevenson FK. Ig VH gene mutational patterns indicate different tumor cell status in human myeloma and monoclonal gammopathy of undetermined significance. Blood 1996; 87(2): 746-55.

28. Jego G, Bataille R, Geffroy-Luseau A, Descamps G, Pellat-Deceunynck C. Pathogen-associated molecular patterns are growth and survival factors for human myeloma cells through Toll-like receptors. Leukemia 2006; 20(6): 1130-7.

29. Perez-Andres M, Almeida J, Martin-Ayuso M, Moro MJ, Martin-Nunez G, Galende J, et al. Clonal plasma cells from monoclonal gammopathy of undetermined significance, multiple myeloma and plasma cell leukemia show different expression profiles of molecules involved in the interaction with the immunological bone marrow microenvironment. Leukemia 2005; 19(3): 449-55. 